Rev. Inst. Med. trop. S. Paulo

39 (5): 283-290, September/October, 1997

\title{
Trypanosoma cruzi: CHEMOTHERAPY WITH BENZNIDAZOLE IN MICE INOCULATED WITH STRAINS FROM PARANÁ STATE AND FROM DIFFERENT ENDEMIC AREAS OF BRAZIL
}

Max Jean de Ornelas TOLEDo(1), Ana Lúcia Falavigna GUILHERME(1), José Carlos da SILVA(2), Marcos Venício de GASPERI(3), Andrea Pereira MENDES(3), Mônica Lúcia GOMES(1) \& Silvana Marques de ARAÚJO(1)

\begin{abstract}
SUMMARY
Strains of Trypanosoma cruzi from different geographical areas have shown different levels of susceptibility to trypanosomicidal drugs. The susceptibility in vivo to benznidazole was investigated in eighteen strains of $T$. cruzi. Twelve were isolated from chronic chagasic patients from different Chagas'disease endemic areas. The other six strains were isolated from the northwestern region of Paraná state; two of them from patients, three from triatomines (Triatoma sordida) and one from wild reservoir (Didelphis sp.). To test drug the infected mice were divided into two groups of twenty. One group was treated with benznidazole for twenty consecutive days and the other group was used as untreated control. The treatment began after detection of the infection by direct blood examination or haemoculture. The control of cure was done through haemoculture and indirect immunofluorescence test. The drug eliminated the inflammatory lesions of the skeletal muscle of mice considered cured and from the heart of most of them. Moreover, the inflammatory lesions were reduced in treated but not cured animals. The T. cruzi strains studied showed a gradient of drug susceptibility that varied from $0 \%$ to $100 \%$. Ten strains were considered sensitive to the treatment (61 to $100 \%$ of cure), one strain was partially sensitive ( $50 \%$ of cure) and seven strains were considered resistant to the treatment ( 0 to $40 \%$ of cure). This variation was observed both in strains of T. cruzi isolated from domestic and sylvatic cycles.
\end{abstract}

KEYWORDS: Trypanosoma cruzi strains; Northwest of Paraná; Chemotherapy; Benznidazole; Mice.

\section{INTRODUCTION}

According to the national serological survey of CAMARGO et al. (1984) $)^{17}$ the prevalence of chagasic infection in the state of Paraná was estimated in $4 \%$. More recently serological investigations of the Basic Parasitology Laboratory at State University of Maringá, Paraná, Brazil, detected $6.29 \%$ of people with positive serology for $T$. cruzi in five counties in the northwestern region of the state ${ }^{23,24}$. These authors observed that these patients were migrants from different Chagas'disease endemic areas of Brazil. In the 70's, a global prevalence of 7.4\% was observed among blood donors of the blood bank of Londrina city, in the northern part of Paraná ${ }^{6}$. Other publications about the disease, done in the 40's and 50's were restricted to demonstrate the presence and domiciliation of infected vectors and positive serology in humans in four counties in the northern region of the state s. $^{95}$.

Benznidazole $(\mathrm{Bz})$ and nifurtimox $(\mathrm{Nfx})$ are the available drugs for treatment of Chagas'disease. They are prescribed only with close medical supervision both for the acute phase of the disease and patients with the indeterminate form of the chronic disease. Both drugs are toxic nitroheterocyclic derivatives used as long-term treatment. These drugs cure only a very low percentage of chronic patients ${ }^{12}$. Contradictory results have been observed by different authors in treatment of patients using $\mathrm{Bz}$ and $\mathrm{Nfx}$ in different phases of the infection. The drug efficacy ranged from $33.3 \%$ to $81 \% 18,19,27,30,31.32$.

Natural resistance of $T$. cruzi to nitroderivatives was suggested as an important factor to explain the low rates of cure detected in chagasic patients. ANDRADE et al. $(1985)^{2}$ suggested that certain types of strains with particular susceptibility to drugs may predominate in specific geographical areas. Drug susceptibility related to geographical distribution of some strains of $T$. cruzi was also observed by FILARDI \& BRENER (1987) ${ }^{22}$. Since only one type of strain would predominate in a particular geographical area, we should consider this factor as responsible for some therapeutic discrepancies observed in different clinical assays ${ }^{2}$. Seventy-seven strains

Financial Support: Fundação Nacional da Saúde (FNS).

(1) Basic Parasitology Sector, Clinical Analysis Department, Univ. Fed. Ouro Preto, Ouro Preto, MG, Brasil

(2) Pathology Sector, Medicine Department. State University of Maringá, P.O.Box 331, 87020-900 Maringá, PR, Brazil.

(3) CNPq/PIBIC Scientific Initiation Scholarship.

Correspondence to: Dr. Max Jean de Ornelas Toledo. Laboratório de Parasitologia - ICEB II, Campus Universitário Morro do Cruzeiro, Universidade Federal de Ouro

Preto, 35400-000 Ouro Preto, MG, Brasil. Fax (031) 559-1679. 
TOLEDO, M. J. de O.; GUILHERME, A. L. F.; SILVA, J. C. da; GASPERI, M. V. de; MENDES, A. P.; GOMES, M. L. \& ARAUJO, S. M. de - Trypanosoma cruzi: chemotherapy with benznidazole in mice inoculated with strains from Paraná State and from different endemic areas of Brazil. Rev. Inst. Med. trop. S. Paulo, 39(5): 283-290, 1997.

isolated of many Brazilian states, and even from other endemic countries, had their susceptibility to the common drugs ( $\mathrm{Bz}$ and $\mathrm{Nfx}$ ) determined in mice ${ }^{2,22}$. However none of them were isolated from Paraná although this state is in the fourth place in the rank of related Chagas' disease cases in Brazil ${ }^{34}$.

T. cruzi stocks isolated from chronic chagasic patients, triatomines and wild animals captured in the domicile and peridomicile in the northwest of Paraná have been studied in our laboratory. These stocks showed low and medium virulence for $\mathrm{C} 3 \mathrm{H} / \mathrm{He}$ mice when the parameters infectivity, parasitaemia and mortality rate were considered ${ }^{29}$.

According to ANDRADE et al. (1985) it is useful to determine the susceptibility in vivo of the parasite strain of a given patient before the specific treatment ${ }^{2}$. Thus, to provide base for the treatment of chagasic patients from northwestern region of Paraná, the susceptibility to benznidazole of their $T$. cruzi strains was determined in albino mice. Treatment was performed in the acute and chronic phases of experimental infection. The response to treatment was also evaluated using histopathological analysis.

\section{MATERIAL AND METHODS}

\section{Strains isolated from human}

Fourteen $T$. cruzi strains were isolated through haemoculture in LIT media ${ }^{21}$ from chronic chagasic patients living in different counties in the north-west of Paraná. These patients are migrants from different Chagas'disease endemic areas of Brazil. They were asked about previously treatment with benznidazole or similar drug. Table 1 summarizes the isolation source and geographical origin of the 18 strains analyzed. Eight out of fourteen human isolates $(57.1 \%)$ were obtained from patients that have lived in the state of Minas Gerais. Two strains were obtained from patients from São Paulo state and one from patient from Alagoas state. It was not possible to determine exactly the origin of 3 human strains (PR-209, PR-399 and PR-443), although the PR-209 strain might have come from Minas Gerais or São Paulo and the PR-399 strain from Bahia or Paraná states according to patients'information. (Table 1). For this work PR-399 and PR-443 strains were considered autochthonous from Paraná.

\section{TABLE 1}

Cure rate obtained with benznidazole in mice inoculated with Trypanosoma cruzi strains from different hosts from the northwestern region of Paraná and patients from different endemic areas.

\begin{tabular}{|c|c|c|c|c|}
\hline $\begin{array}{l}\text { T. cruzi } \\
\text { strains }\end{array}$ & Source & Geographic origin ${ }^{1}$ & $\begin{array}{c}\text { Bz treatment } \\
\text { beginning (i.d.) }{ }^{2}\end{array}$ & $\begin{array}{l}\% \text { of } \\
\text { cure }\end{array}$ \\
\hline $\mathrm{Y}$ & Acute phase patient & São Paulo - SP & 7 & 50 \\
\hline PR- 182 & Chronic phase patient & Itamarandiba - MG & 13 & 15 \\
\hline PR-2259 & $"$ & Virgem da Lapa - MG & 10 & 86 \\
\hline PR-076 & $"$ & Coração de Jesus - MG & 11 & 40 \\
\hline PR-149* & $"$ & Montes Claros - MG & 14 & 100 \\
\hline $\mathrm{PR}-427 *$ & $"$ & Terra Branca / Macaúba - MG & 10 & 61 \\
\hline PR-402 & $"$ & Poté - MG & 13 & 35 \\
\hline PR- 184 & $"$ & Montes Claros - MG & 25 & 31 \\
\hline PR-150* & $"$ & Januária - MG & 17 & 0 \\
\hline PR-209 & $"$ & Montes Claros - MG/Pres. Prudente - SP & 12 & 50 \\
\hline PR-1921 & $"$ & Ipê - SP & 21 & 80 \\
\hline PR-036* & $"$ & São Pedro Turvo - SP & 13 & 75 \\
\hline PR-1256* & $"$ & União de Palmares - AL & 13 & 39 \\
\hline PR-399 & $"$ & Mortugaba $-\mathrm{BA} / 1^{\circ}$ de Maio $-\mathrm{PR}$ & 10 & 100 \\
\hline PR-443 & $"$ & $?$ & 13 & 56 \\
\hline G3 & Didelphis sp & Maringá - PR & 20 & 85 \\
\hline A2.1A & Triatoma sordida & Paiçandú - PR & 19 & 23 \\
\hline $\mathrm{N} 4.2$ & Triatoma sordida & Paiçandú - PR & 21 & 67 \\
\hline N2.6 & Triatoma sordida & Paiçandú - PR & 23 & 90 \\
\hline
\end{tabular}

* Strains isolated from patients under treatment with benznidazole after isolation.

1 Region where patients probably caught the disease.

2 Infection day when experimental treatment began.

? The origin was not possible to be determined. 
TOLEDO, M. J. de O.; GUILHERME, A. L. F.; SILVA, J. C. da; GASPERI, M. V. de; MENDES, A. P.; GOMES, M. L. \& ARAUJO, S. M. de - Trypanosoma cruzi: chemotherapy with benznidazole in mice inoculated with strains from Paraná State and from different endemic areas of Brazil. Rev. Inst. Med. trop. S. Paulo, 39(5): 283-290, 1997.

\section{Strains isolated from triatomines and wild reservoirs}

Three T. cruzi strains were isolated through xenoculture ${ }^{15}$ from Triatoma sordida and one strain was isolated through haemoculture in LIT medium from Didelphis sp. Both the sylvatic triatomines and the mammal reservoir were captured in counties from the northwestern region of Paraná (Table 1).

\section{Animals infection}

Groups of 40 young albino female mice, $18-20 \mathrm{~g}$, were inoculated intraperitoneally with $1.0 \times 10^{3}$ or $1.0 \times 10^{4}$ blood trypomastigotes per animal with each of the strains. The parasites were obtained from infected mice and the inoculum standardized according to BRENER (1962) ${ }^{13}$. In the case of strains with subpatent parasitaemia in mice, the infection was carried out with trypomastigotes produced in M16 medium ${ }^{20}$. The inoculum was determined in a Neubauer chamber and ranged from 0.7 to $18.2 \times 10^{6}$ metacyclic trypomastigotes/animal (Table 2).

\section{Treatment of animals}

The infected animals were separated into two groups of twenty. One group was treated with benznidazole [N-benzyl-2-nitro-1-imidazolacetamide] $100 \mathrm{mg} / \mathrm{kg} /$ day, for twenty consecutive days ${ }^{10,22}$ suspended in water and arabic gum. Each mouse received daily $0.25 \mathrm{ml}$ of the drug suspension by gavage. The treatment began as soon as the infection was confirmed, between the $10^{\text {th }}$ and the $25^{\text {th }}$ day of infection (Table 1). In order to compare the results of the treatment of the experimental murine disease in the acute phase with the one in the chronic phase, groups of animals inoculated with the strains PR-427 and PR-182 were treated in the chronic phase with the same therapeutical procedure. In this case the treatment was initiated on the $90^{\text {th }}$ day of infection.

The mice inoculated by PR-328 strain were not treated due to the low infectivity of this strain (Table 2). The laboratory T. cruzi Y strain (kindly provided by Dr. Egler Chiari) was used as reference.

\section{Confirmation of infection}

For the strains which produced a patent parasitaemia the infection was determined by fresh blood examination. For the ones with subpatent parasitaemia, the infection was determined through haemoculture (HC) of 0.4 to $0.6 \mathrm{ml}$ of blood collected from the orbital venous sinus. Blood was transferred into two tubes containing $4 \mathrm{ml}$ of LIT (liver-infusion tryptose) ${ }^{16}$, incubated at $28^{\circ} \mathrm{C}$ during 30-60 days and examined microscopically for living flagellates.

\section{The indirect immunofluorescence test (IFT)}

Sera were obtained from both treated and untreated animal groups six months after treatment, by punction of the orbital venous sinus. The material was stored at $-20^{\circ} \mathrm{C}$ until the immunofluorescence test was processed according to CAMARGO et al. (1984) $)^{17}$. Epimastigotes forms of $T$. cruzi were used as antigen (Imunocruzi-BIOLAB) with fluorescein conjugated anti-mouse Ig (Sigma Immuno Chemicals). The preparations were examined on the microscope under ultraviolet light. Sera were considered positive when fluorescent in dilutions $\geq 1: 20$.

\section{Control of cure}

Animals treated in the acute phase of the disease were considered cured when both parasitological and serological tests were negative ${ }^{10,22}$. After treatment they were checked by fresh blood examination 3-days a week. Haemoculture was performed 30 days after the end of treatment for treated and untreated animals. Mice showing IFT titer $\geq 1: 20$ were considered a therapeutical failure, independently of the haemoculture results. Animals treated in the chronic phase of infection were considered cured when the haemoculture was negative and when the IFT titer was below the observed in control animals 6 months after the end of treatment ${ }^{1}$. The cure rate was expressed in percentage.

\section{Histopathology}

For the histopathological analysis, mice were classified in 4 experimental groups for each $T$. cruzi strains studied: untreated animals, cured treated animals, not-cured treated animals and uninfected control animals. Two mice were sacrificed six months after the end of treatment (between the $7^{\text {th }}$ and the $8^{\text {th }}$ month of infection) for each group. Tissue

TABLE 2

Inoculum standardization of $T$. cruzi cultured forms grown in M16 medium and inoculated mice infection rates.

\begin{tabular}{|c|c|c|c|c|c|}
\hline \multirow{2}{*}{$\begin{array}{l}\text { T. cruzi } \\
\text { strain } \\
\text { PR-150 }\end{array}$} & \multirow{2}{*}{ 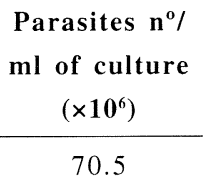 } & \multirow{2}{*}{\begin{tabular}{|l|} 
MT \% \\
64.5 \\
\end{tabular}} & \multirow{2}{*}{$\begin{array}{c}\text { MT no/ } \\
\text { animal } \\
\left(\times \mathbf{1 0}^{6}\right)\end{array}$} & \multicolumn{2}{|c|}{$\begin{array}{c}\mathrm{N}^{\circ} \text { of animals } \\
\text { inoculated/infected }(\%)\end{array}$} \\
\hline & & & & 41 & $41(100.0)$ \\
\hline PR-328 & 30.8 & 5.3 & 0.8 & 40 & $9(22.5)$ \\
\hline G3 & 32.9 & 51.0 & 3.4 & 31 & $30(96.8)$ \\
\hline $\mathrm{A} 2.1 \mathrm{~A}$ & 16.0 & 20.4 & 1.0 & 30 & $27(90.0)$ \\
\hline N2.6 & 49.5 & 22.8 & 3.4 & 30 & $16(53.3)$ \\
\hline $\mathrm{N} 4.2$ & 14.5 & 15.2 & 0.7 & 30 & $27(90.0)$ \\
\hline
\end{tabular}

MT = Metacyclic trypomastigotes. 
TOLEDO, M. J. de O.; GUILHERME, A. L. F.; SILVA, J. C. da; GASPERI, M. V. de; MENDES, A. P.; GOMES, M. L. \& ARAUJO, S. M. de - Trypanosoma cruzi: chemotherapy with benznidazole in mice inoculated with strains from Paraná State and from different endemic areas of Brazil. Rev. Inst. Med. trop. S. Paulo, 39(5): 283-290, 1997.

samples were taken from the heart, skeletal muscle, bladder, diaphragm, liver, spleen, esophagus and small and large intestine. Tissue samples were fixed with $10 \%$ formalin and embedded in paraffin. From each sample three 3 - $\mu$ m-thick sections separated by $20 \mu \mathrm{m}$ intervals were obtained. After hematoxilin-eosin staining, the presence of tissular parasitism was evaluated. The number of inflammatory foci was determined by examining 50 random microscopic fields $(400 \mathrm{X})$ in each section. Spleen sections were examined under oil immersion $(1000 \mathrm{X})$ only for detection of parasites. The degree of mononuclear infiltration was classified as: $0=$ no lesions; $1=$ one inflammatory focus; $2=$ two inflammatory foci; $3=$ three inflammatory foci; $4=$ four inflammatory foci and $5=$ five or more inflammatory foci.

\section{RESULTS}

All patients informed that they were never previously submitted to specific chemotherapy against T. cruzi. The benznidazole susceptibility of six Paraná autochthonous strains ranged from 23 to $100 \%$, similar to the observed with strains originated from other endemic areas (Table 1 and Figure 1). This variation was detected both in the strains isolated from humans and sylvatic cycle.

A concordance of $90.77 \%$ was observed between haemoculture and IFT in 366 mice inoculated with different strains of $T$. cruzi and treated during the acute phase of the disease (Table 3).

Histopathological analysis detected amastigotes only in the heart of untreated mice infected with PR-2259 strain and in the skeletal muscle of untreated mice infected with PR-182 strain (Table 4). There was no amastigote nest on preparations obtained of animals treated and cured and of the ones treated but not cured. Sections from heart and skeletal muscle from the

\section{TABLE 3}

Haemoculture (HC) and indirect immunofluorescence test (IFT) results in 336 mice inoculated with different Trypanosoma cruzi strains, treated and not treated with benznidazole in the acute phase of infection.

\begin{tabular}{ccc}
\hline Haemoculure & \multicolumn{2}{c}{ IFT } \\
\hline & $85(25.3 \%)$ & $25(7.4 \%)$ \\
Negative & $6(1.8 \%)$ & $220(65.5 \%)$ \\
Positive &
\end{tabular}

Concordance between the two methods: 305 (90.8\%).

untreated group displayed more inflammatory foci than the treated not cured one. In the same way, more inflammatory foci were observed in the treated not-cured group than in the treated cured one. Although the results observed in the liver were not so evident as in the heart or skeletal muscle, we observed more severe lesions in the untreated and treated not cured groups, where some perivasculite and necrosis were noticed. The uninfected control group presented no lesions, except one animal that showed one inflammatory focus in the liver.

A rate of cure of $100 \%$ was observed for mice inoculated with the strain PR-427 and treated during the chronic phase. All treated mice presented a negative haemoculture (HC) after treatment while just $12.5 \%$ of the not treated animals presented a negative test (Table 5). Among mice infected with the strain PR-182, $41.2 \%$ of the treated group and $46.2 \%$ of the control group showed a positive $\mathrm{HC}$ after treatment. Thus, for the strain PR-182, the HC done one month after the treatment of the chronic phase $\left(5^{\text {th }}\right.$ month of infection) failed in detecting infection in $53.8 \%$ of the control animals.

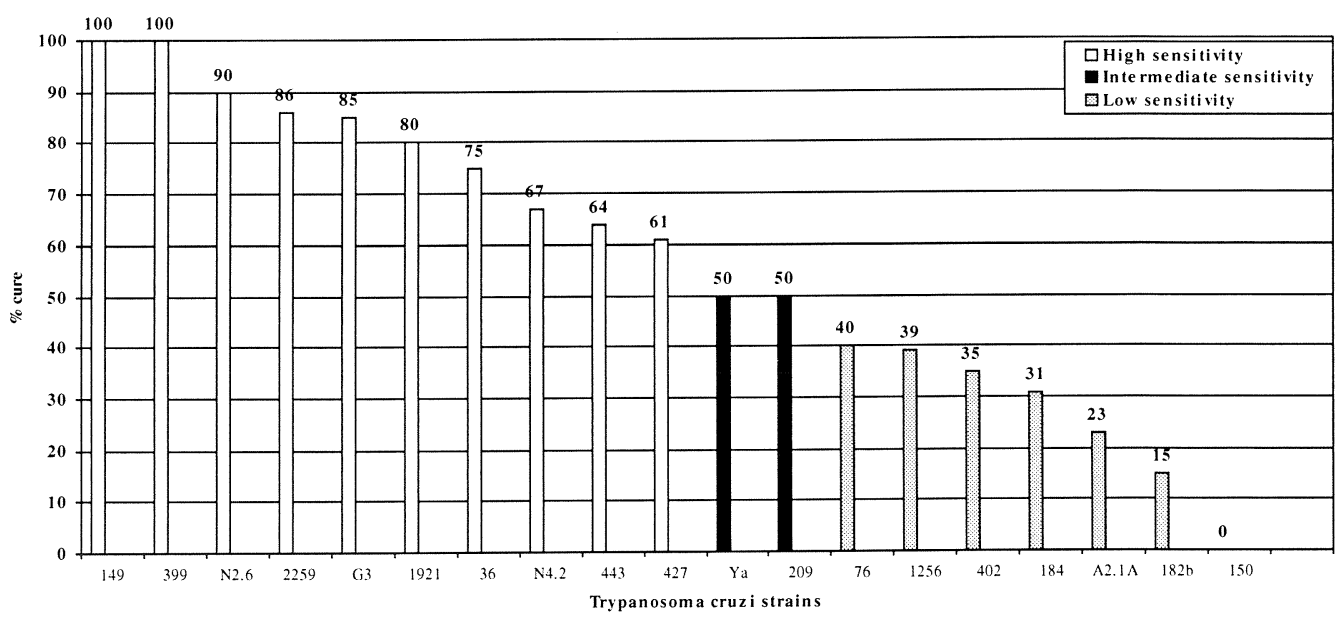

Fig. 1 - Gradient of benznidazole susceptibility of Trypanosoma cruzi strains from Paraná State and from different endemic areas of Brazil, in mice.

$\mathrm{a}=$ The $T$. cruzi $\mathrm{Y}$ strain was used as reference.

$\mathrm{b}=$ Average between two experiments. 
TOLEDO, M. J. de O.; GUILHERME, A. L. F.; SILVA, J. C. da; GASPERI, M. V. de; MENDES, A. P.; GOMES, M. L. \& ARAUJO, S. M. de - Trypanosoma cruzi: chemotherapy with benznidazole in mice inoculated with strains from Paraná State and from different endemic areas of Brazil. Rev. Inst. Med. trop. S. Paulo, 39(5): 283-290, 1997.

TABLE 4

Severity of tissular lesions in mice inoculated with different human Trypanosoma cruzi strains treated with benznidazole in the acute phase of infection and necropsied six months after the end of treatment.

\begin{tabular}{|c|c|c|c|c|c|c|c|c|c|c|}
\hline \multirow[t]{2}{*}{$\begin{array}{l}\text { T. cruzi } \\
\text { strains }\end{array}$} & \multirow{2}{*}{$\begin{array}{c}\text { Inoculum } \\
(\text { BT no } \\
\text { /animal) }\end{array}$} & \multicolumn{3}{|c|}{$\begin{array}{c}\text { Heart } \\
\left(\mathrm{N}^{\circ} \text { inflammatory foci }\right)\end{array}$} & \multicolumn{3}{|c|}{$\begin{array}{c}\text { Skeletal muscle } \\
\left(\mathrm{N}^{\circ} \text { inflammatory foci }\right)\end{array}$} & \multicolumn{3}{|c|}{$\begin{array}{c}\text { Liver } \\
\left(\mathrm{N}^{\circ} \text { inflammatory foci }\right)\end{array}$} \\
\hline & & Untreated & $\begin{array}{c}\text { Treated } \\
\text { not } \\
\text { cured }\end{array}$ & $\begin{array}{l}\text { Treated } \\
\text { cured }\end{array}$ & Untreated & $\begin{array}{c}\text { Treated } \\
\text { not } \\
\text { cured }\end{array}$ & $\begin{array}{l}\text { Treated } \\
\text { cured }\end{array}$ & Untreated & $\begin{array}{c}\text { Treated } \\
\text { not } \\
\text { cured }\end{array}$ & $\begin{array}{l}\text { Treated } \\
\text { cured }\end{array}$ \\
\hline $\mathrm{Y}$ & $10^{4}$ & 0 & 0 & 1 & 5 & 2 & 0 & $5 \mathrm{P}$ & $5 \mathrm{P}$ & 5 \\
\hline PR-1 82 & $10^{4}$ & 4 & 0 & 0 & $3 \mathrm{~A}$ & 0 & 0 & $4 \mathrm{P}$ & 3 & 4 \\
\hline PR-209 & $10^{4}$ & 0 & 0 & 0 & 0 & 1 & 0 & 5 & 3 & 0 \\
\hline PR-1256 & $10^{4}$ & 0 & 1 & 0 & 0 & 1 & 0 & 3 & 2 & 3 \\
\hline PR-2259 & $10^{4}$ & $1 \mathrm{~A}$ & 0 & 0 & 3 & 0 & 0 & 2 & $1 \mathrm{~N}$ & 1 \\
\hline PR-036 & $10^{3}$ & 1 & 1 & 0 & 1 & 0 & 0 & 5 & 2 & 1 \\
\hline PR-1921 & $10^{3}$ & 0 & 0 & 0 & 0 & 0 & 0 & 0 & 0 & 2 \\
\hline PR-149 & $10^{3}$ & 0 & - & 0 & 0 & - & 0 & 0 & 0 & 1 \\
\hline PR-076 & $10^{3}$ & 3 & 1 & 1 & 1 & 1 & 0 & 0 & 0 & 1 \\
\hline
\end{tabular}

BT $=$ blood trypomastigotes.

$0=$ no lesion, 1 = one inflammatory focus, $2=$ two inflammatory foci, $3=$ three inflammatory foci, $4=$ four inflammatory foci and $5=$ five or more inflammatory foci.

$\mathrm{A}=$ amastigote nest, $\mathrm{P}=$ perivasculite, $\mathrm{N}=$ necrosis,$-=$ all animals were cured.

TABLE 5

Haemoculture and indirect immunofluorescence test (IFT) positive percentages in mice infected by Trypanosoma cruzi and treated with benznidazole in the chronic phase (starting at the $90^{\text {th }}$ day of infection).

\begin{tabular}{lcccc}
\hline T. cruzi & \multicolumn{2}{c}{ Haemoculture } & \multicolumn{2}{c}{ IFT } \\
strains & \multicolumn{2}{c}{ N+/T $(\%)$} & \multicolumn{2}{c}{ N+ / T (\%) } \\
& Treated & Untreated & Treated & Untreated \\
\hline PR-427 & $0 / 21(0.0)$ & $14 / 16(87.5)$ & $18 / 18(100)$ & $14 / 15(93.3)$ \\
PR-182 & $7 / 17(41.2)$ & $6 / 13(46.2)$ & $15 / 16(93.8)$ & $13 / 13(100)$ \\
\hline
\end{tabular}

$\mathrm{N}+=$ number of positive animals; $\mathrm{T}=$ total of animals analyzed.

\section{TABLE 6}

IFT antibody titer presented by mice infected with the Trypanosoma cruzi PR-427 strain and treated with benznidazole during the chronic phase (from the $90^{\text {th }}$ day of infection).

\begin{tabular}{ccc}
\hline $\begin{array}{c}\text { Antibody } \\
\text { titer } \#\end{array}$ & \multicolumn{2}{c}{ \% of animals } \\
\hline negative & Treated $^{*}$ & Untreated \\
$1: 10$ & 0.0 & 6.7 \\
$1: 20$ & 0.0 & 0.0 \\
$1: 40$ & 61.6 & 0.0 \\
$1: 80$ & 22.2 & 6.7 \\
$1: 160$ & 5.6 & 20.0 \\
$1: 320$ & 0.0 & 33.3 \\
$1: 640$ & 11.1 & 0.0 \\
$\geq 1: 1280$ & 0.0 & 6.7 \\
\hline
\end{tabular}

*All of the treated animals showed a negative haemoculture after treatment. \#Serum collected six months after the end of treatment ( $10^{\text {th }}$ month of infection)
The IFT was still positive six months after the treatment of the chronic phase in $100 \%$ of the parasitologically cured animals inoculated with the PR-427 strain and $93.8 \%$ from those infected with PR-182 strain (Table 5). The majority $(83.8 \%$ ) of the treated and parasitologically cured animals presented antibody titer from 1:20 to 1:40. On the other hand, $80 \%$ of the not treated group showing a positive $\mathrm{HC}$ had serological titers from $1: 80$ to $\geq 1: 1280$ (Table 6 ).

\section{DISCUSSION}

A large variety of sensibility to $\mathrm{Bz}$ was observed in the strains analyzed in this study. Previous works studying this same parameter ${ }^{2,22}$ and using strains from different regions also demonstrated different levels of sensitivity to Bz. However, some reports showed predominance of resistant or sensitive strains in different geographic areas.

Intra-specific variations of $T$. cruzi populations have been shown through biological, biochemical, immunological, chemotherapeutic and molecular parameters ${ }^{11,36,37}$. Although the T. cruzi strains analyzed in this study seem to present a homogeneous biological behaviour ${ }^{29}$, the same was not observed in relation to sensibility to $\mathrm{Bz}$. These findings confirm previous data $^{22}$, where no correlation was established between sensibility to drug and malignity of the infection evaluated by other parameters: pre-patent period, curves of parasitaemia or mortality rates. Nevertheless, ANDRADE et al., $(1985)^{2}$ and BARNABÉ et al., $(1983)^{8}$ found a correlation between $\mathrm{Bz}$ and $\mathrm{Nfx}$ sensibility with morphobiological behavior and isoenzymic patterns, respectively.

The majority of chagasic patients attended at the Chagas' Disease Laboratory of the State University of Maringá was born 
TOLEDO, M. J. de O.; GUILHERME, A. L. F.; SILVA, J. C. da; GASPERI, M. V. de; MENDES, A. P.; GOMES, M. L. \& ARAUJO, S. M. de - Trypanosoma cruzi: chemotherapy with benznidazole in mice inoculated with strains from Paraná State and from different endemic areas of Brazil. Rev. Inst. Med. trop. S. Paulo, 39(5): 283-290, 1997.

in other states. Although they live in the northwestern region of Paraná nowadays, they could have been infected in other states of Brazil. So, we decided to isolate $T$. cruzi samples from naturally sylvatic vectors and reservoirs infected and captured in counties from Paraná. The four strains isolated from these sources also presented a variation in their susceptibility to $\mathrm{Bz}$. Three out four samples (strains N2.6, N4.2 and G3) were sensitive to $\mathrm{Bz}$ and one was naturally resistant (strain A2.1A).

Some authors have reported correlation between drug sensibility of $T$. cruzi strains and their geographical origin ${ }^{2,22}$. Our results showed that $T$. cruzi strains isolated from the sylvatic cycle in Paraná presented a sensibility rate to $\mathrm{Bz}$ similar to strains isolated in Santa Catarina state, but different from the one observed in Rio Grande do Sul state. Strains isolated from sylvatic vectors and reservoirs in Santa Catarina showed rates of cure between 60 to $100 \%$ ( 8 strains) in mice treated with Bz. One strain from this state was partially resistant (SC16 strain, $47 \%$ of cure) and another naturally resistant (SC28 strain, $0 \%$ of cure $)^{38}$. Strains from Rio Grande do Sul and Argentina showed a higher rate of cure $(93.3 \text { to } 100 \%)^{22}$.

The sensibility pattern to $\mathrm{Bz}$ of all strains studied is very similar to the one observed with strains from Minas Gerais, where a varied degree of sensibility was detected ${ }^{22}$. In fact, the Northern region of Paraná is considered an endemic area of the disease and was partly colonized by migrants from the endemic areas specially of Minas Gerais (57.1\% of the patients) and São Paulo in the 40's and 50's.

These patients were treated and have been followed up for a later comparison of the results of their treatment to the results obtained in experimentally infected mice with their strains. This correlation is difficult to be done since the control of cure of human Chagas' disease demands prolonged follow-up involving parasitological tests, as well as conventional and unconventional immunological tests ${ }^{26}$. A correlation around $90 \%$ was observed between the experimental and the clinical results in 15 cases $^{4,22}$. The parasite strain might be the key factor influencing the chemotherapeutic success, since comparable results were obtained in 2 different hosts.

In our report we observed that the histopathological lesions in mice inoculated with different $T$. cruzi strains and not treated were mild and focal ( 1 to 7 inflammatory foci/section). These mild alterations can be related to the phase of the infection in which they were necropsied and the low inoculum in relation to other histopathological studies in which severe lesions were $\operatorname{seen}^{5.33}$. Also, these results could be explained by the low and medium virulence of the strains analysed ${ }^{29}$.

The parasites were found only in the not treated animals. Consequently, the $\mathrm{Bz}$ not only suppressed the parasitaemia but also caused the removal of the parasites from the tissues. Despite the low number of parasites in the chronic phase of infection and the low sensibility of the hematoxilin-eosin method in detecting of amastigotes ${ }^{7}$, muscle parasitism was observed in two post-mortem examined mice in the $7^{\text {th }}-8^{\text {th }}$ month of infection. The few inflammatory lesions observed in the cured treated animals is probably due to parasite antigen residues similarly to the observed for other authors ${ }^{5,33}$.

Our data confirm the high sensibility of haemoculture for cure verification in mice treated in the acute phase. These results correlated with serological test (IFT). However, for the control of cure of murine chronic experimental infection the use of other parasitological techniques besides haemoculture is also recommended, since our findings suggest that the sensibility of this technique in this phase of the disease depends on the $T$. cruzi strain. By the way, our results confirm previous findings ${ }^{3}$ which showed that for the same $T$. cruzi strain the efficacy of the treatment of murine chronic infection could be better than the treatment of the acute phase.

New techniques should be considered for control of cure, since the conventional serology remains positive after the successful treatment of experimental chronical infection, although with decrease in IFT titer. Additionally, the haemoculture fails in detecting the infection and the complement mediated lysis test ( $\mathrm{LMCo}$ ) requires a long time and high standard workmanship. Molecular techniques such as the polymerase chain reaction (PCR), which has been evaluated for the diagnosis and control of cure in humans ${ }^{14}$, would be another option. Nevertheless, the inoculation of triturated organs of treated animals in newborn mice has presented good results. This approach confirm the therapeutical failure of the animals which presented a previous negative haemoculture after treatment ${ }^{28}$

\section{RESUMO}

\section{Trypanosoma cruzi: quimioterapia com benzonidazol em camundongos inoculados com cepas do Estado do Paraná e de outras áreas endêmicas do Brasil}

Cepas de Trypanosoma cruzi de diferentes áreas geográficas têm mostrado diferentes graus de suscetibilidade a drogas tripanosomicidas. A suscetibilidade in vivo ao benzonidazol foi investigada em 18 cepas de $T$. cruzi. Doze foram isoladas de pacientes chagásicos crônicos de diferentes áreas endêmicas da doença de Chagas. Seis cepas foram procedentes da região Noroeste do Paraná: 2 isoladas de humanos, 3 de triatomíneos da espécie Triatoma sordida e 1 do reservatório silvestre do parasito Didelphis sp. No teste da droga, camundongos inoculados foram divididos em 2 grupos de 20 . Um grupo foi tratado com benzonidazol por 20 dias consecutivos e o outro grupo foi utilizado como controle não tratado. $\mathrm{O}$ tratamento dos animais foi iniciado após constatação da infecção, feita através de exame direto do sangue ou hemocultura. O controle de cura foi feito utilizando a hemocultura e a imunofluorescência indireta, realizadas respectivamente, 30 e 180 dias após o término do tratamento. A droga eliminou as lesões inflamatórias do músculo esquelético dos camundongos considerados curados e do coração da maioria destes animais e as diminuiu naqueles animais 
TOLEDO, M. J. de O.; GUILHERME, A. L. F.; SILVA, J. C. da; GASPERI, M. V. de; MENDES, A. P.; GOMES, M. L. \& ARAUJO, S. M. de-Trypanosoma cruzi: chemotherapy with benznidazole in mice inoculated with strains from Paraná State and from different endemic areas of Brazil. Rev. Inst. Med. trop. S. Paulo, 39(5): 283-290, 1997.

tratados não curados. As cepas de $T$. cruzi estudadas apresentaram um gradiente de suscetibilidade a droga que variou de $0 \%$ a $100 \%$. Dez cepas foram consideradas sensíveis ao tratamento (61 a $100 \%$ de cura), uma cepa foi parcialmente sensível ( $50 \%$ de cura) e 7 cepas foram consideradas resistentes ( 0 a $40 \%$ de cura). Esta variação foi observada tanto com as cepas isoladas do ciclo doméstico quanto com aquelas isoladas do ciclo silvestre.

\section{ACKNOWLEDGEMENTS}

To Sandra Vieira da Silva for technical support in the laboratory.

\section{REFERENCES}

1. ANDRADE, S. G.; FREITAS, L. A. R.; PEYROL, S.; PIMENTEL, A. R. \& SADIGURSKY, M. - Experimental chemotherapy of Trypanosoma cruzi infection: persistence of parasite antigens and positive serology. in parasitologically cured mice. Bull. Wld. Hlth. Org., 69: 191-197, 1991.

2. ANDRADE, S. G.; MAGAlHÃES, J. B. \& PONTES, A. L. - Evaluation of chemotherapy with benznidazole and nifurtimox in mice infected with Trypanosoma cruzi strains of different types. Bull. Wld. Hlth. Org., 63: $721-726,1985$.

3. ANDRADE, S. G.; MAGALHÃES, J. B. \& PONTES, A. L. - Terapêutica da fase crônica da infecção experimental pelo Trypanosoma cruzi com o benzonidazol e o nifurtimox. Rev. Soc. bras. Med. trop., 22: 113-118, 1989.

4. ANDRADE, S. G.; RASSI, A.; MAGALHÃES, J. B.; FERRIOLLI FILHO, F. \& LUQUETTI, A. O. - Specific chemotherapy of Chagas' disease: a comparison between the response in patients and experimental animals inoculated with the same strains. Trans. roy. Soc. trop. Med. Hyg., 86: 624-626, 1992.

5. ANDRADE, S. G.; STOCKER-GUERRET, S.; PIMENTEL, A. R. \& GRIMAUD, J. A. - Reversibility of cardiac fibrosis in mice chronically infected with Trypanosoma cruzi, under specific chemotherapy. Mem. Inst. Oswaldo Cruz, 86: $187-200,1991$

6. BALDY, J. L S.; TAKAOCA L; PEREIRA, J. D ; CALIXTO, A A. \& DUARTE, E. L. - Prevalência da infecção por Trypanosoma cruzi, em 1975, em dois bancos de sangue de Londrina, Paraná, Brasil. Rev. Saúde públ. (S. Paulo), 12: 409-416, 1978.

7. BARBOSA, A. J. A.; GOBBI, H.; LINO, B. T. et al. - Comparative study between the conventional method and immunoperoxidase method in research of chronic chagasic cardiopathy. Rev. Inst. Med. trop. S. Paulo, 28: 91-96, 1986.

8. BARNABÉ, C.; TIBAYRENC, M. \& DUJARDIN, J. P. - Trypanosoma cruzi: a pharmacological comparison of some bolivian isoenzymatic strains. Ann. Soc. belge Méd. trop., 63: 319-324, 1983.

9. BARRETTO, M. P. - Epidemiologia. In: BRENER, Z. \& ANDRADE, Z. Trypanosoma cruzi e Doença de Chagas. Rio de Janeiro, Guanabara Koogan, 1979. p. 89-151.

10. BRENER, Z.; CANÇADO, J. R.; GALVÃO, L. M. C. et al. - An experimental and clinical assay with ketoconazole in the treatment of Chagas' disease. Mem. Inst. Oswaldo Cruz, 88: 149-153, 1993

11. BRENER, Z.; COSTA, A. G. \& CHIARI, C. A. - Differences in the susceptibility of Trypanosoma cruzi strains to active chemotherapeutic agents. Rev. Inst. Med. trop. S. Paulo, 18: 450-455, 1976.

12. BRENER, Z. - Recent advances in the chemotherapy of Chagas' disease. Mem. Inst. Oswaldo Cruz, 79: 149-155, 1984

13. BRENER, Z. - Therapeutic activity and criterion of cure on mice experimentally infected with Trypanosoma cruzi. Rev. Inst. Med. trop. S. Paulo, 4: 389-396, 1962.
14. BRITO, C.; CARDOSO, M. A.; RAVEL, C. et al. - Trypasonoma cruzi: parasite detection and strain discrimination in chronic chagasic patients from Northeastern Brazil using PCR amplification of kinetoplast DNA and nonradioactive hybridization. Exp. Parasit., 81: 462-471, 1995.

15. BRONFEN, E.; ROCHA, F. S. A.; MACHADO, G. B. N. et al. - Isolamento de amostras do Trypanosoma cruzi por xenodiagnóstico e hemocultura de pacientes na fase crônica da doença de Chagas. Mem. Inst. Oswaldo Cruz, 84: 237-240, 1989.

16. CAMARGO, E. P. - Growth and differentiation in Trypanosoma cruzi. Origin of metacyclic trypanosomes in liquid media. Rev. Inst. Med. trop. S. Paulo, 6: 93-100, 1964.

17. CAMARGO, M.E.; SILVA, G. R.; CASTILHO, E. A. \& SILVEIRA, A. C. - Inquérito sorológico da prevalência da infeç̧ão chagásica no Brasil, 1975-1980. Rev. Inst. Med. trop. S. Paulo, 26: 192-204, 1984.

18. CANÇADO, J. R. - Eficácia terapêutica do benzonidazol na doença de Chagas aguda humana. Rev. Soc. bras. Med. trop., 24 (supl I): 20-21, 1991.

19. CANÇADO, J. R. - Tratamento específico. In: CANÇADO, J. R. \& CLUSTER, M., ed. Cardiopatia chagásica. Belo Horizonte, Fundação Carlos Chagas, 1985. p. 277-355.

20. CHIARI, E.; MARQUES DE ARAÚJO, S. \& CARNEIRO, M. - Meios empobrecidos em nutrientes na diferenciação epimastigota-tripomastigota do Trypanosoma cruzi. In: REUNIÃO ANUAL SOBRE PESQUISA BÁSICA EM DOENÇA DE CHAGAS, 7, Caxambú, MG, 1980. p. B141.

21. CHIARI, E.; DIAS, J. C. P.; LANA, M. \& CHIARI, C. A. - Hemocultures for the parasitological diagnosis of human chronic Chagas' disease. Rev. Soc. bras. Med. trop., 22: 19-23, 1989.

22. FILARDI, L. \& BRENER, Z. - Susceptibility and natural resistance of Trypanosoma cruzi strains to drugs used clinically in Chagas' disease. Trans. roy. Soc. trop. Med. Hyg., 81: 755-759, 1987.

23. GOMES, M. L.; BERTOLINI, D. A.; SILVEIRA, T. G. V.; LONARDONI, M. V. C. \& ARRAES, S. M. A. A. - Investigação sorológica da doença de Chagas e isolamento do Trypanosoma cruzi em indivíduos de 5 municípios da região Noroeste do Paraná. Rev. Soc. bras. Med. trop., 25 (supl. III): 94, 1992.

24. GOMES, M. L.; RAMOS, M.; SILVEIRA, T. G. V.; DIAS, M. L. G. G. \& MARQUES DE ARAÚJO, S. - Isolation and biological characterization of Trypanosoma cruzi strains in North of Paraná State, Brazil. Mem. Inst. Oswaldo Cruz, 85 (supl. I): 16, 1990.

25. HIGUCHI, M. L.; BRITO, T. de; REIS, M. M. et al. - Correlation between Trypanosoma cruzi parasitism and myocardial inflammatory infiltrate in human chronic chagasic myocarditis: light microscopy and immunohistochemical findings. Cardiovasc. Path., 2: 101-106, 1993.

26. KRETTLI, A. U.; CANÇADO, J. R. \& BRENER, Z. - Criterion of cure of human Chagas' disease after specific chemotherapy: recent advances. Mem. Inst. Oswaldo Cruz, 79: 157-164, 1984.

27. LEDESMA, O. - Tratamento de la infección chagásica aguda. Rev. Fed. argent. Cardiol., 17: 232-233, 1988

28. MALDONADO, R. A.; MOLINA, J.; PAYARES, G. \& URBINA, J. A. Experimental chemotherapy with combinations of ergosterol biosynthesis inhibitors in murine models of Chagas'disease. Antimicrob. Agents Chemother., 37: 1353-1359, 1993.

29. MARQUES DE ARAÚJO, S.; OLIVEIRA, P. J. G.; TOLEDO, M. J. O. \& GOMES, M. L. - Caracterização biológica de cepas de Trypanosoma cruzi isoladas de pacientes chagásicos residentes no Noroeste do Paraná. Rev. Sìc. bras. Med. trop., 27 (Supl II): 152-153, 1994.

30. PRATA, A.; MACEDO, V.; PORTO, G. et al. - Tratamento da doença de Chagas pelo nifurtimox (Bay-2502). Rev. Soc. bras. Med. trop., 9: 297-304, 1975. 
TOLEDO, M. J. de O.; GUILHERME, A. L. F.; SILVA, J. C. da; GASPERI, M. V. de; MENDES, A. P.; GOMES, M. L. \& ARAUJO, S. M. de - Trypanosoma cruzi: chemotherapy with benznidazole in mice inoculated with strains from Paraná State and from different endemic areas of Brazil. Rev. Inst. Med. trop. S. Paulo, 39(5): 283-290, 1997.

31. RASSI, A. \& FERREIRA, H. O. - Tentativas de tratamento específico da fase aguda da doença de Chagas com nitrofuranos em esquemas de duração prolongada. Rev. Soc. bras. Med. trop., 5: 235-262, 1971.

32. RASSI, A. - Tratamento etiológico da doença de Chagas. Arq. bras. Cardiol., 38: $277-281,1981$.

33. SEGURA, M. A.; MOLINA DE RASPI, E. \& BASOMBRIO, M. A. Reversibility of muscle and heart lesions in chronic. Trypasonoma cruzi infected mice after late tripanosomicidal treatment. Mem. Inst. Oswaldo Cruz, 89 213-216, 1994

34. SILVEIRA, A. C. \& RESENDE, D. F. - Epidemiologia e contro ? da transmissão vetorial da doença de Chagas no Brasil. Rev. Soc. bras. Med. trop., 27 (supl. III): $11-22,1994$

35. SOUZA ARAÚJO, H. C. - A doença de Chagas no Paraná. Mem. Inst. Oswaldo Cruz, 52: 477-485, 1954.
36. STEINDEL, M.; DiAS NETO, E.; MENEZES, C. L. P.; ROMANHA, A. J. \& SIMPSON, A. J. G. - Random amplified polymorphic DNA analysis of Trypanosoma cruzi strains. Molec. Biochem. Parasit., 60: 71-80, 1993.

37. TIBAYRENC, M. \& AYALA, F. J. - Isozyme variability in Trypanosoma cruzi, the agent of Chagas' disease: genetical, taxonomical and epidemiological significance. Evolution, 42: 277-292, 1988

38. TOLEDO, M. J. O. - Influência da resposta imune sobre a quimioterapia específica da doença de Chagas experimental em camundongos. Belo Horizonte, 1991. (Tese de Mestrado).

Recebido para publicação em 16/12/1996 Aceito para publicação em 30/10/1997 